\title{
Sciendo \\ PATHS TO EXPLAIN EMPLOYEE JOB SATISFACTION. A FUZZY-SET ANALYSIS
}

doi:10.2478/mape-2018-0072

Date of submission of the article to the Editor: 05/2018

Date of acceptance of the article by the Editor: 07/2018

MAPE 2018, volume 1, issue 1, pp. 569-576

Dr Eng. Magdalena Gębczyńska

Assoc. Prof. Dr Eng. Anna Kwiotkowska

Silesian University of Technology, Poland

\begin{abstract}
Job satisfaction is one of the most researched topics in management literature taking into consideration the fact that it has been found out that this concept has many practical implications in the workplace. Job satisfaction is very complex phenomenon which is influenced by numerous factors. Previous studies provide a partial view of job satisfaction, because they are usually focused on the relationship between a single factor and job satisfaction, without taking a global view to indicate how different factors simultaneously affect job satisfaction. The purpose of this paper is to investigate how different factors such as: work family balance, teamwork, personal environment fit, job security and supervisor support simultaneously influence job satisfactions. The sample of the study includes employees of Polish small and medium enterprises (SMEs). Fuzzy-set qualitative comparative analysis is used to analyze data collected in surveys from 274 employees. The results contribute to research on job satisfaction by outlining several combinations of factors which create a paths to explain employee job satisfaction: (1) teamwork and supervisor support, (2) personal environment fit, job security and supervisor support with absence of work family balance, (3) work family balance, job security and supervisor support.
\end{abstract}

Keywords: job satisfaction, fuzzy-set qualitative comparative analysis, SMEs

\section{INTRODUCTION}

Job satisfaction is a term first advanced by Hoppock (1935), who defines job satisfaction as the psychological and physiological aspects of employees' satisfaction with job environmental factors. According to Hoppock (1935) job satisfactions is a mixture of psychological, physiological and environmental factors that makes a person to acknowledge: "I am contented with my job". Satisfaction of employees (Job satisfaction-JS) is an emotional condition of the individual about his/her position at work (Warr and Inceoglu, 2012). According to Allen and Wilburn (2002) employee satisfaction influenced employee productivity, absenteeism and retention, and the success of any organization is directly link to the satisfaction of the employees who embody that organization, and that retaining talented people is critical to the success of any organization. The final effect of employees' work depends on his/her satisfaction, which is expressed in profit that the employee creates. Kenny et al. (2016) identified two sub-scale of job satisfaction: (1) work environment satisfaction, (2) work hours and wages satisfaction. Job satisfaction is considered to be the most important tool for employee retention. Job satisfaction refers to how employees perceive their jobs (McShane and Glinow, 2005). It is an emotional state resulting from experiences at work. If employees experience high satisfaction with their jobs, it may create a pleasurable emotional state (Bartolo and Furlonger, 1999) and a positive reaction with the organization (Feinstein, 2002). According to Moyes et al. (2008) the employee satisfaction may be described as how pleased an employee is with his or her position of employment. Job satisfaction is very complex phenomenon which is influenced by numerous factors. The additional factors that are very closely connected with employees' satisfaction, for example 
are: absenteeism, fluctuation, organizational commitment and motivation. Employee satisfaction has been widely studied in the past literature. Previous studies provide a partial view of job satisfaction, because they are usually focused on the relationship between a single factor and job satisfaction, without taking a global view to indicate how different factors simultaneously affect job satisfaction. Determining what factors simultaneously influence workers' job satisfaction has become a growing point of interest for organizations. This research posits that a combination of different factors affects employee job satisfaction, and the aim of this study is to investigate how different factors influence job satisfactions. Accordingly, this empirical study adopts a qualitative comparative analysis using fuzzy sets (fsQCA) to explore the connections between employee job satisfaction and the chosen factors.

This study contributes to the literature by investigating the collective effect of different employee factors on job satisfaction. Second, the study extends the literature by using an uncommon methodology in the field of management, the fuzzy set methodology.

\section{THEORETICAL FRAMEWORK}

Satisfaction of employees is related to the expectations of employees and it can be influenced and increased through meeting employee expectations regarding salary, relationship amongst co-workers, comfortable working environment, training and career opportunities (Sageer et al., 2012). Having good relationships with the colleagues, high salary, good working conditions, training and education opportunities, career developments or any other benefits may be related with the increasing of employee satisfaction (Sageer et al., 2012). There are empirical research towards identifying determinants of job satisfaction and evidence suggests that important factors include socio-demographic variables (e.g. gender, age, marital status, educational level) and domain-specific variables such as dispositional influences (e.g. personality traits) (Judge and Bono, 2001) and work situational influences (e.g. job challenge, being acknowledged, job security) (Kovach, 1995). Examining the factors and determinants that create paths to explain and understand job satisfaction phenomenon is important from the organizational point of view, because it can indicate the future directions of strategic activities that can help achieve a higher level of job satisfaction. Sageer et al. (2012) have identified numerous factors that make employees satisfied or dissatisfied with jobs, and these factors fall into two broad variables: (a) those relating to the organization and (b) those relating to the personal characteristics of the employees. In paper we concern on those relating to the organization. Based on critical literature review we chose following factors: work family balance, teamwork, personal environment fit, job security and supervisor support.

According to Judge and Klinger (2007), increased satisfaction is related to an individual's well-being, and dissatisfaction leads to discontent in personal life. Work family balance is a level at which individuals are as satisfied with their work life as their family life. Individuals, who have reasonable balance between in their job roles and personal lives, are more satisfied and productive at work (Reynolds, 2005; Saeed and Faroogi, 2014). Work family balance plays a vital role in shaping lives of individuals and also in organizing their lives (Carlson, 2013).

Teamwork is examining by scientists due to the idea that work teams are able to generate greater returns than individuals alone (Ilgen et al., 2005). There is a natural desire of human beings to interact with others, and teamworks make use of a remarkable influence on the satisfaction of employees (Sageer et al., 2012). Communicating and collaborating within a team, sharing the knowledge, and prioritizing the group over the individual outcomes are important team features that enhance the benefits of teamwork (Patterson et al., 2005). Chang et al. (2009) showed that interprofessional teamwork was one of the most important predictors of job satisfaction. The teamwork influences the job satisfaction, it means that the 
better teamwork will result in higher satisfaction (Musriha, 2013). Khuong and Tien (2013) also indicated that teamwork had significant positive association with job satisfaction.

The extent to which people fit their work environments has significant consequences on satisfaction, performance, stress, productivity, and turnover of employees. Better fit is associated with better outcomes (Su et al., 2014). All person-environment fit theories share the following assumptions: people seek out and create environments that allow them to behaviorally manifest their traits (e.g. dominant individuals seek leadership positions), person-environment fit is a reciprocal and ongoing process whereby people shape their environments and environments shape people (Rounds and Tracey, 1990). Person environment fit is the extent to which individual and characteristics of environment match (Kristof-Brown et al., 2005; Brown, 2011), and can be achieved through training employees to match their skills with organizational and work requirements.

One of the most consistent findings in the job satisfaction literature is that the effect of job security on job satisfaction is large and significant (Kraimer et al., 2005). Researches have shown that job security induces organizational commitment of workers, which refers to the degree to which a worker identifies with his/her work or organization and its goals and the willingness to maintain membership in the organization (Apkan, 2013). Guest (2004) discovered that low job security and working conditions had adverse effect on employee commitment and job satisfaction. Job satisfaction arising from job security is a major factor affecting the quality of the employer-employee relationship (Nikolaou et al.,2005). Job security is an employee's assurance or confidence that they will keep their current job. Perceived job security is when an individual is employed for a longer time period in an organization with no subsequent decline in his pay, status, and pension rights (Clark, 2005; Clark et al., 2010). Employees with a high level of job security have a low probability of losing their job in the near future (Sageer et al., 2012).

Rowold et al. (2014) propose that the leadership style of an employee's supervisor positively affects the employee's organizational commitment and job satisfaction style of an employee's supervisor positively affects the employee's organizational commitment and job satisfaction. A good working relationship with your supervisor is essential since, at every stage, you need his or her professional input, constructive criticism, and general understanding (Sageer et al., 2012). Cahill et al. (2015) found that supervisor support influences employee job satisfaction, employee engagement, organizational commitment, productivity and performance. Cahill et al. (2015) and Albrecht et al. (2015) agreed that supervisors must be active participants in relationship building activities to increase employee job satisfaction and employee engagement.

\section{METHODOLOGY OF RESEARCH}

The sample of the study includes employees of a Polish SMEs, and the fieldwork contains information from 363 surveys (November 2016 - February 2017). After the exclusion of incomplete questionnaires, data for the analysis comprises 274 valid surveys (a response rate of $75,48 \%$ ). The survey includes five scales (work family balance, teamwork, personal environment fit, job security and supervisor support) in the form of statements to which respondents indicate their level of agreement/disagreement on a five - point Likert scale. All item loadings are higher than 0.7. An extensive review of the relevant literature supports the validity of the scales (see Table 1).

From a psychometric perspective, one single-item overall measure captures job satisfaction was used. The use of single-item measures to operationalize this construct (Cronbach Alpha $=0.929$ ) compares favorably with the use of multiple-item measures (Dolbier et al., 2005; Wanous et al., 1997). 
Table 1

Scales measurements

\begin{tabular}{|l|l|c|}
\hline \multicolumn{1}{|c|}{ Construct } & \multicolumn{1}{|c|}{ Adapted from } & Cronbach Alpha \\
\hline Work family balance & $\begin{array}{l}\text { Construct was measured using Carlson (2013)scale with some } \\
\text { minor modifications and additions and it consisted of 16 items }\end{array}$ & 0.968 \\
\hline Teamwork & $\begin{array}{l}\text { Construct was measured by 5 items from Patterson et al. } \\
(2005)\end{array}$ & 0.841 \\
\hline Personal environment fit & Construct was measured by 13 items from Brown (2011). & 0.953 \\
\hline Job security & $\begin{array}{l}\text { Construct was measured using 11 items from Kraimer, Wayne, } \\
\text { Liden, Sparrowe (2005) and Clark (2005) }\end{array}$ & 0.936 \\
\hline Supervisor support & $\begin{array}{l}\text { Construct was measured by 7 items from Graen, Uhl-Bie } \\
(1995)\end{array}$ & 0.816 \\
\hline
\end{tabular}

Differently from previous studies in which mainly use structural equation modeling (SEM), hierarchical regression analysis or meta-analytic combinations to examine job satisfaction this study adopts fuzzy set Qualitative Comparative Analysis (fsQCA) to better understand the antecedents of job satisfaction. Contrary to correlational methods which estimate the net effect of an independent variable on a dependent variable, fsQCA identifies the conditions that lead to a given outcome (Cheng, et al., 2013; Schneider et al., 2010; Stokke, 2007). In this way, fsQCA supplements conventional correlational analyses thanks to its three main advantages: (1) asymmetry (i.e., the relationships between independent and dependent variables are treated as asymmetric), (2) equifinality (i.e., multiple pathways lead to the same outcome), and (3) causal complexity (i.e., combinations of causal antecedent of job satisfaction, and hence, the focus is not on net effects, but on combinatorial effects) (Fiss, 2011; Ganter and Hecker, 2014; Skarmeas et al.,2014).

The fs/QCA 2.5 software developed by Ragin (2008) was used to analyze the data. Fs/QCA's is based in a set-theory approach that develops causal claims by means of supersets and sub-sets (Ragin, 2008). The first stage of the analysis identifies the various factors that work in combination to influence job satisfaction. The raw data was then calibrated into fuzzy sets (Ragin, 2008). Fuzzy sets allow researchers to account for the varying degree of membership of cases to a particular set by using the anchors of 1 to designate "fully in" a particular set, 0 for non-membership (fully out), and 0.5 as the point of maximum ambiguity to mean neither in, nor out, of a particular set. The crossover point (or the point of maximum ambiguity) designates when a case is more in or more out of the set. Table 2 shows the calibration process and indicates the transformation of both the outcome and the antecedent conditions into fuzzy terms.

Table 2

Distribution of each variable and its corresponding set

\begin{tabular}{|l|c|c|c|}
\hline \multicolumn{1}{|c|}{ Variable } & $\begin{array}{c}\text { Full } \\
\text { non-membership (0.05) }\end{array}$ & Crossover point (0.5) & Full membership (0.95) \\
\hline Work family balance & 0.160 & 1.500 & 2.753 \\
\hline Teamwork & 0.237 & 2.383 & 4.810 \\
\hline Personal environment fit & 0.248 & 3.064 & 5.632 \\
\hline Job security & 0.314 & 3.037 & 5.960 \\
\hline Supervisor support & 0.258 & 3.568 & 5.798 \\
\hline Job satisfaction & 0.332 & 2.314 & 4.389 \\
\hline
\end{tabular}

The next stage includes the analysis of the truth table, which consists of all logically possible combinations of condition sets (Fiss, 2011). After that, using Boolean algebra, fsQCA computes the commonalities among the configurations that lead to the outcome. Finally, the Quine-McCluskey algorithm provides a logical reduction of statements (Fiss, 2007). At this stage, two parameters are in order: (a) coverage and (b) consistency. The former indicates the empirical relevance of a solution (the higher the better), and the latter quantifies the extent to which cases that share similar conditions yield the same outcome. 


\section{RESULTS}

The results was presented in Table 3 . In this table, each row represents a configuration of causal conditions with their corresponding raw coverage, unique coverage and solution consistency. The numbers at the bottom of the table represent the coverage and consistency of the solution as a whole. Utilizing the notation system from Ragin and Fiss (2008), each column in the Table 3 represents a configuration of conditions linked to the respective outcome. Full circles $(\bullet)$ indicate the presence of a condition while barred circles $(\boldsymbol{\theta})$ indicate a condition's absence., blank spaces indicate "don't care". Each panel represents the alternative causal combinations or paths for the outcome (Ragin, 2008). These are consecutively numbered $\mathrm{S} 1, \mathrm{~S} 2$ and $\mathrm{S} 3$.

According to the results of the analysis, the solution yields coverage close to $58 \%$ and consistency of $92 \%$. The first path (solution) of the conditions S1 combines teamwork and supervisor support to achieve job satisfaction. This path indicates that communicating and collaborating within a team, sharing the knowledge, and prioritizing the group over the individual outcomes connected with leadership style, and a good working relationship with supervisor and his or her professional input, constructive criticism, and general understanding lead to job satisfaction.

Table 3

Configurations for job satisfaction

\begin{tabular}{|c|c|c|c|}
\hline \multirow{2}{*}{ Condition (factors) } & \multicolumn{3}{|c|}{ Paths } \\
\hline & S1 & S2 & S3 \\
\hline Work family balance & & $\theta$ & \\
\hline \multicolumn{4}{|l|}{ Teamwork } \\
\hline \multicolumn{4}{|l|}{ Personal environment fit } \\
\hline \multicolumn{4}{|l|}{ Job security } \\
\hline \multicolumn{4}{|l|}{ Supervisor support } \\
\hline Consistency & 0.93 & 0.92 & 0.91 \\
\hline Raw coverage & 0.29 & 0.43 & 0.51 \\
\hline Unique coverage & 0.01 & 0.02 & 0.07 \\
\hline Solution consistency & & 0.92 & \\
\hline Solution coverage & & 0.58 & \\
\hline
\end{tabular}

The second path (solution) of the conditions S2 combines personal environment fit, job security and supervisor support with absence of work family balance lead to job satisfaction. This configuration indicate that when personal environment fit is achieved connected with an employee's assurance that they will keep their current job and supervisor support and employees can achieve positive level of job satisfaction even if reconciling work and family is difficult. These employees enjoy being at work, even at certain personal costs.

The third path (solution) of the conditions S3 that emerges from the analysis indicates that a combination of work family balance, job security and supervisor support also lead to job satisfaction. This path address another support source of employees in addition to work family balance. The presence of work family balance in connection with job security and supervisor support leads to job satisfaction. Notably, in all three configurations supervisor support is a significant factor through which employees achieve a positive level of job satisfaction.

\section{DISCUSSION AND CONCLUSION}

The present results contribute to research on job satisfaction by outlining several combinations of factors which create a paths to explain employee job satisfaction. Specially, 
a high level of supervisor support and job security connected with personal environment fit (S2) or work family balance (S3) foster a high level job satisfaction. Another path leads to high level of job satisfaction is connection supervisor support with family balance (S1).

The results corroborate previous research on employee satisfaction examining important factors such as: work family balance, teamwork, personal environment fit, job security and supervisor support. However, while previous studies focus on the single factors affect job satisfaction, this study contributes to different paths lead to job satisfaction by studying the effect of all of selected conditions simultaneously. In addition, research on HRM, psychology, and management can also benefit from the approach and methodology that this study adopts. Despite QCA is used in information science and operations research, this methodology is largely absent from the management literature.

The results of this research also have practical implications for managers because they may provide them with a more holistic understanding of the paths lead to job satisfaction. This research has several limitations, the most critical of which relates to the data source. The data in this study come from a limited research sample - Polish SMEs, which may reduce the generalizability of the results. Future research could replicate this study in other companies and countries or regions. Additionally, future studies could include other variables (e.g. gender, autonomy, age, education, promotion and career development) to examine the possible mediating or moderating roles of such variables in the associations with job satisfaction.

\section{REFERENCES}

Albrecht, S., Bakker, A., Gruman, J., Macey, W. and Saks, A. (2015). Employee engagement, human resource management practices and competitive advantage: An integrated approach. Journal of Organizational Effectiveness: People and Performance, 2, pp.7-35.

Allen, D.R. and Wilburn, M. (2002). Linking Customer and Employee Satisfaction to the Bottom Line. American Society for Quality, Milwaukee.

Apkan, C. P. (2013). Job security and job satisfaction as determinants of organizational commitment among university teachers in Cross River State, Nigeria. British Journal of Education, 1(2), pp. 82-93.

Bartolo, K. and Furlonger, B. (1999). Leadership and job satisfaction among aviation fire fighters in Australia. Journal of Managerial Psychology, 15, 87-97.

Brown, J.L. (2011). Measuring the impact of person-environment fit and its affective outcomes - A case study of International Cooperation and Development Fund Master of Education Thesis. National Taiwan Normal University, Taipei, Taiwan, pp. 1-122.

Cahill, K. E., McNamara, T. K., Pitt-Catsouphes, M. and Valcour, M. (2015). Linking shifts in the national economy with changes in job satisfaction, employee engagement and work-life balance. Journal of Behavioral and Experimental Economics, 56, pp. 40-54.

Carlson, D. S. (2013). Work-Family Balance and Supervisor Appraised Citizenship Behavior: The link of Positive affect. Institute of Behavioral and Applied Management, pp. 87-106.

Chang, W.Y., Ma, J.C., Chiu, H.T., Lon, K.C. and Lee, P.H. (2009). Job satisfaction and perceptions of quality of patient care, collaboration and teamwork in acute care hospitals. Journal of Advanced Nursing, Vol. 65, pp. 1946-55.

Cheng, C. F., Chang,M. L. and Li, C. S. (2013). Configural paths to successful product innovation. Journal of Business Research, 66(12), pp. 2561-2573.

Clark, L. J. (2005). Moderators of the effects of perceived job insecurity: A comparison of temporary and permanent employees. Ph.D dissertation. Queensland University of Technology.

Clark, A., Knabe, A., Rätzel, S. (2010). Boone or bane? Others' unemployment, well-being and job insecurity. Labour Economics, 17(1), pp. 52-61.

Dolbier, C. L., Webster, J. A., McCalister, K. T., Mallon, M. W. and Steinhardt, M. A. (2005). Reliability and validity of a single-item measure of job satisfaction. American Journal of Health Promotion, 19(3), pp. 194-198.

Feinstein, A.H. (2002). A study of relationships between job satisfaction and organizational commitment among restaurant employees. Journal of Managerial Psychology, 23(7), pp. 33-57.

Fiss, P. C. (2007). A set-theoretic approach to organizational configurations. Academy of Management Review, 32(4), pp. 1180-1198.

Fiss, P. C. (2011). Building better causal theories: A fuzzy set approach to typologies in organization research. Academy of Management Journal, 54(2), pp. 393-420. 
Ganter, A. and Hecker, A. (2014). Configurational paths to organizational innovation: Qualitative comparative analyses of antecedents and contingencies. Journal of Business Research, 67(6), pp. $1285-1292$.

Guest, D.E. (2004). Flexible employment contract, the psychological contract and employee outcomes: An empirical analysis and review of the evidence. International Journal of Management Review. $5 / 6$ (1) 1-19.

Graen, G. B. and Uhl-Bien, M. (1995). Relationship-based approach to leadership: Development of leader-member exchange (LMX) theory of leadership over 25 years: Applying a multi-level multi-domain perspective. Leadership Quarterly, 6(2), pp. 219-247.

Hoppock, R. (1935). Job Satisfaction. American, New York: Harper and Brothers.

Judge, T. A. and Bono, J. E. (2001). Relationship of core self-evaluations traits - self-esteem, generalized self-efficacy, locus of control, and emotional stability - with job satisfaction and job performance: A meta-analysis. Journal of Applied Psychology, 86(1), pp. 80-92.

Ilgen, D. R., Hollenbeck, J. R., Johnson,M. and Jundt, D. (2005). Teams in organizations: From inputprocess-output models to IMOI models. Annual Review of Psychology, 56, pp. 517-543.

Judge, T. A. and Klinger, R. (2007). Job satisfaction: Subjective well-being at work. In: M. Eid \& R. Larsen (Eds.), The science of subjective well-being. New York: Guilford Publications, pp. 393413.

Kenny, P., Reeve, R. and Hall, J. (2016). Satisfaction with nursing education, job satisfaction, and work intentions of new graduate nurses. Nurse Education Today, 36, pp. 230-235.

Kovach, K. A. (1995). Employee motivation: Addressing a crucial factor in your organization's performance. Employment Relations Today, 22(2), pp. 93-107.

Kristof-Brown, A. L., Zimmerman, R. D. and Johnson, E. C. (2005). Consequences of individual's fit at work: A metaanalysis of person-job, person-organization, person-group, and person-supervisor fit. Personnel Psychology, Vol. 58 (2), pp. 281-342.

Khuong, M. N. and Tien, B.D. (2013). Factors influencing employee loyalty directly and indirectly through job satisfaction - A study of banking sector in Ho Chi Minh City. International Journal of Current Research and Academic Review, 1 (4), pp. 81-95.

Kraimer, M.L., Wayne, S.J., Liden, R.C. and Sparrowe, R.T. (2005).The Role of Job Security in Understanding the Relationship Between Employees' Perceptions of Temporary Workers and Employees' Job Performance. Journal of Applied Psychology 90 (2), pp.389-398,

McShane, S.L. and Von Glinow, M.A. (2005). Organizational Behavior (3th ed.). India: Tata McGrawHill Inc.

Moyes, G. D., Shao, L. P. and Newsome, M. (2008). Comparative analysis of employee job Satisfaction in the accounting profession. Journal of Business \& Economics Research, 6(2), pp. 65-81.

Musriha (2013). Influence of Teamwork, Environment on Job Satisfaction and Job Performance of the Cigarette Rollers at Clove Cigarette Factories in East Java, Indonesia. Developing Country Studies, 3(2), pp.32-40.

Nikolaou, A., Theodossiou, I. and Vasileiou, E.G. (2005). Does job security increase job satisfaction? A study of the European experience. In: 2nd World Conference SOLE/EALE, European Association of Labour Economists, San Francisco.

Patterson, M. G, West, M. A, Shackleton, V. J., Dawson, J.F., Lawthom, R., Maitlis, S., Robinson, D. and Wallace, A. M. (2005). Validating the organizational climate measure: Links to managerial practices, productivity and innovation. Journal of Organizational Behavior, 26(4), pp. 379-408.

Ragin, C.C. (2008). Redesigning Social Inquiry: Fuzzy Sets and Beyond. Chicago, IL: University of Chicago Press.

Ragin, C. C. and Fiss, P. (2008). Net effects versus configurations: an empirical demonstration. in C. C. Ragin (Ed.), Redesigning Social Inquiry, 1, pp. 190-212, Chicago and London: University of Chicago Press.

Reynolds, J. (2005). In the face of conflict: Work-life conflict and desired work hour adjustments. Journal of Marriage and Family, 67, pp. 1313-1331.

Rounds, J. B., Tracey, T. J. (1990). From trait-and-factor to person-environment fit counseling: Theory and process. In W. B. Walsh, S.J.Osipow (Eds.), Career ounseling: Contemporary topics in vocational psychology. Hillsdale, NJ: Erlbaum, pp. 1-44.

Rowold, J., Borgmann, L. and Bormann, K. (2014). Which leadership constructs are important for predicting job satisfaction, affective commitment, and perceived job performance in profit versus nonprofit organizations? Nonprofit Management and Leadership, 25(2), pp.147-164.

Saeed, K. and Farooqi, Y. A. (2014). Examining the relationship between Work life balance, Job stress and Job satisfaction among university teachers. International Journal of multidisciplinary sciences and engineering, 5(6), pp. 9-16.

Sageer, A., Rafat, D. S. and Agarwal, M. P. (2012). Identification of Variables Affecting Employee Satisfaction and Their Impact on the Organization. Journal of Business and Management, 5(1), pp. 32-39. 
Schneider, M. R., Schulze-Bentrop, C. and Paunescu, M. (2010). Mapping the institutional capital of high-tech firms: A fuzzy-set analysis of capitalist variety and export performance. Journal of International Business Studies, 41(2), pp. 246-266.

Skarmeas, D., Leonidou, C. N. and Saridakis, C. (2014). Examining the role of CSR skepticism using fuzzy-set qualitative comparative analysis. Journal of Business Research, 67(9), pp. 1796-1805.

Stokke, O. S. (2007). Qualitative comparative analysis, shaming, and international regime effectiveness. Journal of Business Research, 60(5), pp. 501-511.

Su, R., Murdock, C. D., Rounds, J., Hartung, P., Savickas, M. and Walsh, B. (2014). Personenvironment fit. APA Handbook of Career Intervention, pp. 81-98.

Wanous, J. P., Reichers, A. E., and Hudy, M. J. (1997). Overall job satisfaction: How good are singleitem measures? Journal of Applied Psychology, 82(2), pp. 247-252.

Warr, P. and Inceoglu, I. ( 2012). Job engagement, job satisfaction, and contrasting associations with person-job fit. Journal of Occupational Health Psyhology, Vol. 17(2), pp. 129-138. 